\title{
Oxidative stress-induced formation of covalently linked ribulose-1,5-bisphosphate carboxylase/oxygenase large subunit dimer in tobacco plants
}

\author{
Jasmina Kurepa and Jan A. Smalle* (1)
}

\begin{abstract}
Objective: Many abiotic stresses cause the excessive accumulation of reactive oxygen species known as oxidative stress. While analyzing the effects of oxidative stress on tobacco, we noticed the increased accumulation of a specific protein in extracts from plants treated with the oxidative-stress inducing herbicide paraquat which promotes the generation of reactive oxygen species primarily in chloroplasts. The primary objectives of this study were to identify this protein and to determine if its accumulation is indeed a result of oxidative stress.

Results: Here we show that the paraquat-induced protein is a covalently linked dimer of the large subunit of ribulose-1,5-bisphosphate carboxylase (LSU). Increased accumulation of this LSU dimer was also observed in tobacco plants exposed to ultra-small anatase titanium dioxide nanoparticles $\left(\mathrm{nTiO}_{2}\right)$, which because of their surface reactivity cause oxidative stress by promoting the generation of superoxide anion. $\mathrm{nTiO}_{2}$ nanoparticle treatments also caused a decline in the chloroplast thylakoid proteins cytochrome $\mathrm{f}$ and chlorophyll a/b binding protein, thus confirming that covalent LSU dimer formation coincides with loss of chloroplast function.
\end{abstract}

Keywords: Rubisco, Oxidative stress, Dimer, Paraquat, Titanium dioxide nanoparticles

\section{Introduction}

Ribulose-1,5-bisphosphate

carboxylase/oxygenase (Rubisco) catalyzes the rate-limiting step of $\mathrm{CO}_{2}$ fixation in photosynthesis and is thus the key enzyme in the global carbon cycle [1]. It is a multi-subunit enzyme complex composed of eight small and eight large subunits (LSU) with the latter assembling in the complex as LSU dimers that contain the active sites [2]. Rubisco, being a catalytically very inefficient enzyme, became an important target for improving photosynthetic efficiency, an effort that involved intense research aimed at understanding the regulation of Rubisco catalytic mechanisms,

\footnotetext{
*Correspondence: jsmalle@uky.edu

Plant Physiology, Biochemistry, Molecular Biology Program, Department of Plant and Soil Sciences, College of Agriculture, Food and Environment, University of Kentucky, Lexington, KY 40546, USA
}

holoenzyme assembly mechanisms and pathways that lead to complex disassembly and degradation [3-6].

Degradation of Rubisco is an important catabolic process. Because of its abundance, Rubisco is the most significant cellular storage of nitrogen and the remobilization of this nitrogen by proteolysis of Rubisco is a hallmark of senescence and stress responses [7]. The current view of Rubisco degradation indicates that the choice of proteolytic pathway may largely be dictated by which endogenous and environmental factors are triggering the stress response [8]. In addition to fragmentation, it was shown in the aquatic monocot Lemna gibba that small and large Rubisco subunit can form covalently linked dimers after exposure to ultraviolet radiation stress [9].

Here we describe the formation of covalently linked LSU dimers in burley tobacco exposed to oxidative stress. Oxidative stress was induced by the reactive oxygen species (ROS)-generating herbicide paraquat (PQ) 
and by titanium dioxide nanoparticles $\left(\mathrm{nTiO}_{2}\right)$. PQ is a redox-active herbicide that accepts electrons from photosystem I and transfers them to oxygen thus loading the cell with superoxide radicals [10]. Superoxide radicals are further metabolized into $\mathrm{H}_{2} \mathrm{O}_{2}$ and in turn, into hydroxyl radicals. All these ROS damage cellular components and induce the oxidative stress response [11-13]. ROS-induced damage is also an important component of nanomaterial-induced toxicity. Due to the increased use of nanomaterials in all areas of technology and thus their presence in the biosphere, analyses of their mechanisms of nanotoxicity have been intensified and in recent years, they showed that one of the common mechanisms of toxicity is the generation of ROS and concomitant oxidative stress [14-16]. Exposure to $\mathrm{nTiO}_{2}$ for example leads to increased intracellular ROS in cells of all tested species and leads to cellular damage in function of the size, dose and surface reactivity of the nanoparticles used [17-20].

\section{Main text \\ Materials and methods \\ Plant growth}

Burley tobacco seeds (KT 204LC variety) were obtained from F.W. Rickard Seeds, Inc. (Winchester, KY). Seeds were sterilized ( $5 \mathrm{~min}$ in 70\% ethanol, followed by $20 \mathrm{~min}$ in $50 \%$ commercial bleach solution and 3 rinses in sterile water) and sown on Murashige and Skoog medium with $3 \%$ sucrose ( $\mathrm{pH}$ 5.7). Plants were grown in axenic cultures in a controlled environment chamber in continuous light $\left(25^{\circ} \mathrm{C} ; 80 \mu \mathrm{mol} \mathrm{m}{ }^{-2} \mathrm{~s}^{-1}\right)$.

\section{Treatments}

Plants were analyzed when 2 months old. For all experiments, the laminar part of mature leaves of three plants were pooled per sample and each treatment was done in triplicate. Paraquat (Sigma, methyl viologen) stock was prepared as a $100 \mathrm{mM}$ aqueous solution. Anatase $\mathrm{nTiO}_{2}$ (5-15 nm, 15 wt\% nanopowder dispersion; US Research Nanomaterials) stock was prepared by diluting the commercial suspension in methanol $(1: 9 \mathrm{v} / \mathrm{v})$. Immediately before treatments, the stock was further diluted in distilled water to a final concentration of $2 \mathrm{mM}$ and sonicated for 5 min.

\section{Immunoblotting analyses}

Protein extraction and immunoblotting analyses were performed as previously described [21]. The primary antibodies used were: anti-Rubisco LSU antibody (RbL form I and II, Agrisera, dilution 1:10,000), anti-Chlorophyll a/b binding protein (Cab) antibody (Lhcb1, Agrisera, 1:10,000), anti-Cytochrome $\mathrm{f}(\mathrm{Cyt} \mathrm{f})$ antibody (PetA, Agrisera, 1:10,000), anti-Heat Shock Protein 90 (HSP90) antibody (at-115, Santa Cruz Biotechnology, 1:5000) and
anti-Binding Immunoglobulin Protein (BiP) antibody (at95; Santa Cruz Biotechnology, 1:5000). The secondary antibody used was horseradish peroxidase-conjugated anti-rabbit IgG goat antibodies obtained from Santa Cruz Biotechnology. Immunoblots were developed using SuperSignal West Femto substrate (Thermo-Pierce) using a ChemiDoc ${ }^{\mathrm{TM}}$ XRS molecular imager (Bio-Rad).

\section{Protein identification}

SDS-PAGE gels for protein identification by mass spectrometry were prepared following the published guidelines [22]. After separation, proteins were stained with Coomassie Brilliant Blue R-250, destained and the band of interest was excised from the gel. After extensive washing with water, the sample was submitted for analysis. Mass spectrometric analysis was performed at the Proteomics Core Facility of the University of Kentucky. The protein was digested with trypsin and peptides were extracted and analyzed by LC/MS/MS on an Orbitrap mass spectrometer. The resulting spectra were submitted for a database similarity analysis and the matches were ranked by score. The search program, MASCOT, was adjusted to analyze the "other green plants" database.

\section{Results}

Young leaves of 2-month-old sterile grown burley tobacco plants were incubated in water or $100 \mu \mathrm{M}$ aqueous solution of PQ in light for $4 \mathrm{~h}$. After that, one PQtreated sample was washed and incubated in water for another $4 \mathrm{~h}$ to test for recovery. Analyses of total protein extracts resolved on SDS/PAGE gels showed that PQ treatment leads to a marked induction of a $\sim 125 \mathrm{kDa}$ protein that can be observed after total protein extracts transferred to nitrocellulose membranes were stained by Ponceau $S$, which is a reversible protein dye with low sensitivity (Fig. 1a). To identify the PQ-induced protein, we ran preparative denaturing gels, excised the induced protein and identified it using mass spectrometry. These analyses revealed with high certainty (64\% coverage) that the accumulated protein is Rubisco LSU. Using the MASCOT search program, the top hit was LSU from Nicotiana debneyi (Additional file 1). There were 469 other significant Rubisco matches (as a testimony to sequence conservation of this protein among plant species). On denaturing SDS-PAGE protein gels, LSU has an apparent molecular mass of $55 \mathrm{kDa}$ (Fig. 1a). Because the oxidative stress-induced LSU protein was approximately twice the size of the LSU monomer, we concluded that this LSU version is a covalent dimer.

Next, we performed immunoblotting analyses to confirm that the induced protein is indeed LSU. We treated leaves of 1-month-old in vitro grown tobacco plants with $100 \mu \mathrm{M}$ PQ for 2 or $4 \mathrm{~h}$ (Fig. 1b). Immunoblotting 

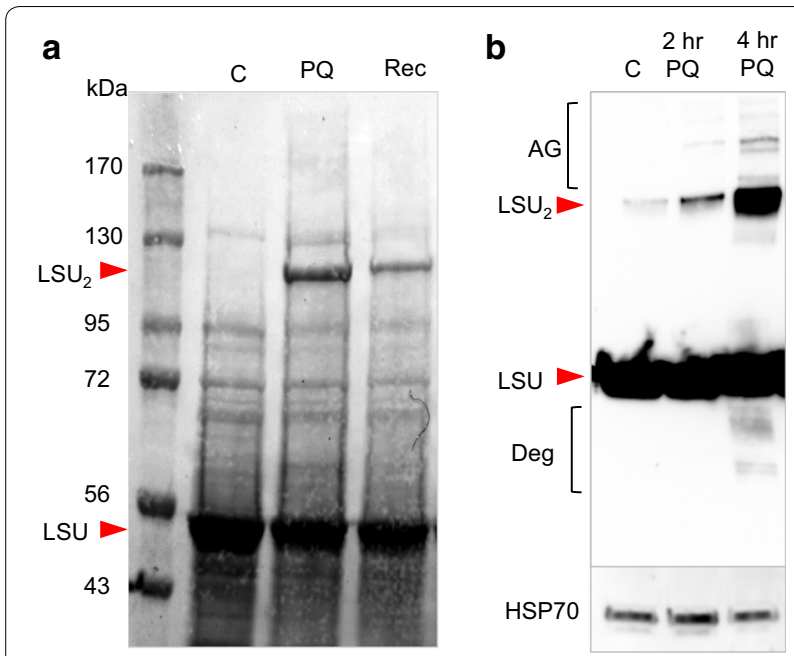

Fig. 1 Formation of $L S U$ dimer after paraquat $(P Q)$ treatment. a Plants were incubated for $4 \mathrm{~h}$ in water (control, C) or $100 \mu \mathrm{M} \mathrm{PQ} \mathrm{(PQ}$ and $\operatorname{Rec}$ ). The recovery (Rec) sample was incubated in water for an additional $4 \mathrm{~h}$. Protein extracts were resolved on a $7.5 \%$ separating acrylamide gels and transferred to nitrocellulose membrane. The Ponceau S staining of the membrane is shown. LSU, the large subunit of Rubisco. The size of the protein mass markers is shown on the left. b Plants were treated for 2 and $4 \mathrm{~h}$ with $100 \mu \mathrm{M} \mathrm{PQ}$. Total protein extracts were resolved on a $7.5 \%$ separating acrylamide gels and transferred to nitrocellulose membranes. The membranes were probed with anti-LSU antibodies or anti-HSP70 antibodies (loading control)

analyses of total protein extracts showed that increased treatment time led to an increase in LSU dimer level. In addition, immunoblotting analyses showed that both high molecular weight aggregates as well as degradation products of LSU are formed during persistent chloroplast-generated oxidative stress (Fig. 1b).

Next, we tested whether another oxidative stress inducer can also lead to the formation of a covalently linked LSU dimer and chose to test the effect of exposure to $\mathrm{nTiO}_{2}$. For our experiments, we used a sublethal dose of ultra-small (aggressive and cell wall- and membrane-permeable) anatase $\mathrm{nTiO}_{2}[20,23]$. We incubated excised leaves of 2-month-old in vitro grown tobacco plants in water or an aqueous suspension of $2 \mathrm{mM}$ nanoparticles for different times. Immunoblotting analyses revealed that the denaturation-resistant LSU dimer is indeed formed and accumulates to a high level after prolonged $(>12 \mathrm{~h})$ treatments with $\mathrm{nTiO}_{2}$ (Fig. 2). Total protein extracts of $\mathrm{nTiO}_{2}$-treated tobacco were also analyzed using antibodies against the chloroplast thylakoid proteins chlorophyll a/b binding protein (Cab) and cytochrome $\mathrm{f}$ (Cyt $\mathrm{f})$. Both proteins were less abundant in extracts of the nanoparticle-treated leaves, suggesting that nanoparticles impacted the overall function of tobacco chloroplasts (Fig. 2). In contrast, the levels

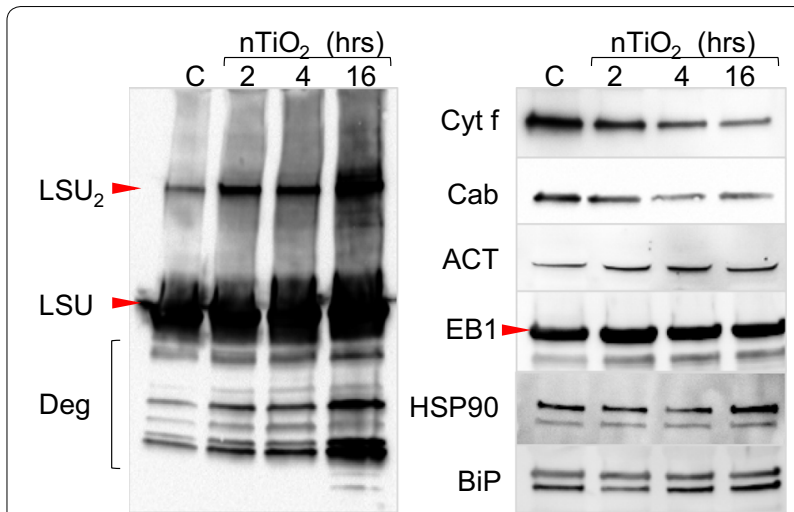

Fig. 2 Formation of LSU dimer after nanoparticle treatment. Plants treated for 2, 4 or $16 \mathrm{~h}$ with ultra-small anatase $\mathrm{TiO}_{2}$ nanoparticles $\left(\mathrm{nTiO}_{2}\right)$ were used for the isolation of total protein extracts. Protein extracts were resolved on 4-20\% gradient separating acrylamide gel and transferred to a nitrocellulose membrane. The membranes were probed with antibodies specific for the protein(s) indicated on the left-hand side of each immunoblot. Deg, degradation products

of cytoskeletal proteins actin and EB1 and the levels of chaperoning proteins HSP90 and BiP did not change in response to the nanoparticle treatments (Fig. 2).

\section{Discussion}

Burley is a mutant tobacco variety with characteristic yellow-green leaves. Although the genetic nature of this leaf phenotype remains unknown, it has been recently shown that key genes related to chlorophyll biosynthesis and photosynthesis are significantly down-regulated in burley plants and that this causes a decrease in chlorophyll content and a reduction of photosynthesis efficiency when compared to other tobacco varieties [24]. In previous studies, we have analyzed total protein extracts of other tobacco varieties (e.g., Petit Havana SR1) and of the model plant Arabidopsis exposed to oxidative stress and we did not observe any accumulation of covalently linked LSU dimer in total extracts [25-32]. However, the presence of a stress-induced covalently linked LSU dimer was inadvertently shown in a study describing the effects of UV treatments on Rubisco stability in L. gibba [9]. This study describes the stress-induced formation of covalent dimers of the large and small Rubisco subunits in duckweed and a number of terrestrial monocots and dicots [9]. It is now well-established that ultraviolet irradiation causes oxidative stress [33]. Thus, one can hypothesize that the formation of covalently linked LSU dimer is an aspect of oxidative stress-induced damage in plant chloroplasts and that due to the nature of the genetic make-up of burley, this phenomenon can be more easily observed in this tobacco variety. 


\section{Limitations}

In addition to the question if oxidative stress-induced covalent LSU dimer linkage is universal to all plants, we have unanswered questions about the mechanism of the stress-induced covalent LSU dimer formation. We currently do not know if oxidative stress promotes the formation of the covalent bonds between LSU subunits between specific amino acid residues or for example, between a less defined number of oxidized amino acids.

\section{Additional file}

Additional file 1. Database similarity analysis. The PQ-induced protein (Fig. 1a) was trypsin-digested and the peptides were analyzed by LC/ MS/MS on an Orbitrap mass spectrometer. The resulting spectra were submitted for a database similarity analysis, and the matches were ranked by score.

\section{Abbreviations}

BiP: Binding Immunoglobulin Protein; Cab: chlorophyll a/b binding protein; Cyt f: cytochrome f; HSP90: Heat Shock Protein 90; LSU: large subunit of ribulose-1,5-bisphosphate carboxylase/oxygenase; $\mathrm{nTiO}_{2}$ : titanium dioxide nanoparticles; PQ: paraquat; Rubisco: ribulose-1,5-bisphosphate carboxylase/ oxygenase.

\section{Authors' contributions}

JK and JS have designed the study, interpreted the results and have written the manuscript. JK has performed all the experiments. Both authors read and approved the final manuscript.

\section{Acknowledgements}

The burley tobacco (KT 204) seeds were a gift from Anne Jack (KTRDC, Lexington KY, USA). We thank The Proteomics Core Facility at the University of Kentucky for the identification of the paraquat-induced protein.

\section{Competing interests}

The authors declare that they have no competing interests.

\section{Availability of data and materials}

All the data are contained within this manuscript. All research materials are commercially available.

\section{Consent for publication}

Not applicable.

\section{Ethics approval and consent to participate} Not applicable.

\section{Funding}

This work was funded by the USDA National Institute of Food and Agriculture competitive grants program project 2015-67021-22997 and by the Kentucky Tobacco Research and Development Center (KTRDC). The funding bodies had no role in the design of the study and collection, analysis, and interpretation of data and in writing the manuscript.

\section{Publisher's Note}

Springer Nature remains neutral with regard to jurisdictional claims in published maps and institutional affiliations.

Received: 15 November 2018 Accepted: 22 February 2019 Published online: 28 February 2019

\section{References}

1. Erb TJ, Zarzycki J. A short history of RubisCO: the rise and fall (?) of nature's predominant $\mathrm{CO}_{2}$ fixing enzyme. Curr Opin Biotechnol. 2018;49:100-7.

2. Vitlin Gruber A, Feiz L. Rubisco assembly in the chloroplast. Front Mol Biosci. 2018;5:24.

3. Hayer-Hartl M. From chaperonins to Rubisco assembly and metabolic repair. Protein Sci. 2017;26(12):2324-33.

4. Lin MT, Occhialini A, Andralojc PJ, Parry MA, Hanson MR. A faster Rubisco with potential to increase photosynthesis in crops. Nature. 2014;513(7519):547-50

5. Wilson RH, Hayer-Hartl M. Complex chaperone dependence of Rubisco biogenesis. Biochemistry. 2018;57(23):3210-6.

6. Bracher A, Whitney SM, Hartl FU, Hayer-Hartl M. Biogenesis and metabolic maintenance of Rubisco. Annu Rev Plant Biol. 2017:68:29-60.

7. Hörtensteiner S, Feller U. Nitrogen metabolism and remobilization during senescence. J Exp Bot. 2002;53(370):927-37.

8. Feller U, Anders I, Mae T. Rubiscolytics: fate of Rubisco after its enzymatic function in a cell is terminated. J Exp Bot. 2008;59(7):1615-24.

9. Ferreira RM, Franco E, Teixeira AR. Covalent dimerization of ribulose bisphosphate carboxylase subunits by UV radiation. Biochem J. 1996;318(Pt 1):227-34.

10. Duke SO. Overview of herbicide mechanisms of action. Environ Health Perspect. 1990;87:263-71.

11. Apel K, Hirt H. Reactive oxygen species: metabolism, oxidative stress, and signal transduction. Annu Rev Plant Biol. 2004;55:373-99.

12. Del Rio LA. ROS and RNS in plant physiology: an overview. J Exp Bot. 2015;66(10):2827-37.

13. Møller IM, Jensen PE, Hansson A. Oxidative modifications to cellular components in plants. Annu Rev Plant Biol. 2007;58:459-81.

14. Fu PP, Xia Q, Hwang HM, Ray PC, Yu H. Mechanisms of nanotoxicity: generation of reactive oxygen species. J Food Drug Anal. 2014;22(1):64-75.

15. Buzea C, Pacheco II, Robbie K. Nanomaterials and nanoparticles: sources and toxicity. Biointerphases. 2007:2(4):MR17-71.

16. Ma C, White JC, Zhao J, Zhao Q, Xing B. Uptake of engineered nanoparticles by food crops: characterization, mechanisms, and implications. Annu Rev Food Sci Technol. 2018:9:129-53.

17. Arora H, Doty C, Yuan Y, Boyle J, Petras K, Rabatic B, Paunesku T, Woloschak G. Titanium dioxide nanocomposites. In: Challa S, Kumar SR, editors. Nanomaterials for the life sciences, Vol 8: nanocomposites. Weinheim: WILEY-VCH Verlag GmbH \& Co. KGaA; 2010. p. 1-42.

18. Fenoglio I, Greco G, Livraghi S, Fubini B. Non-UV-induced radical reactions at the surface of $\mathrm{TiO}_{2}$ nanoparticles that may trigger toxic responses. Chemistry. 2009;15(18):4614-21.

19. Lei Z, Mingyu S, Xiao W, Chao L, Chunxiang Q, Liang C, Hao H, Xiaoqing $L$, Fashui $H$. Antioxidant stress is promoted by nano-anatase in spinach chloroplasts under UV-B radiation. Biol Trace Elem Res. 2008;121(1):69-79.

20. Wang S, Kurepa J, Smalle JA. Ultra-small $\mathrm{TiO}_{2}$ nanoparticles disrupt microtubular networks in Arabidopsis thaliana. Plant Cell Environ. 2011;34(5):811-20.

21. Kurepa J, Smalle JA. Assaying transcription factor stability. Methods Mol Biol. 2011;754:219-34

22. Gundry RL, White MY, Murray Cl, Kane LA, Fu Q, Stanley BA, Van Eyk JE. Preparation of proteins and peptides for mass spectrometry analysis in a bottom-up proteomics workflow. Curr Protoc Mol Biol. 2009;10:10-25.

23. Kurepa J, Paunesku T, Vogt S, Arora H, Rabatic BM, Lu J, Wanzer MB, Woloschak GE, Smalle JA. Uptake and distribution of ultrasmall anatase $\mathrm{TiO}_{2}$ Alizarin red $\mathrm{S}$ nanoconjugates in Arabidopsis thaliana. Nano Lett. 2010;10(7):2296-302.

24. Li Y, Yang H, Chang D, Lin S, Feng Y, Li J, Shi H. Biochemical, physiological and transcriptomic comparison between burley and flue-cured tobacco seedlings in relation to carbohydrates and nitrate content. Molecules. 2017;22(12):2126.

25. Kurepa J, Van Montagu M, Inze D. Expression of sodCp and sodB genes in Nicotiana tabacum: effects of light and copper excess. J Exp Bot. 1997:48(317):2007-14.

26. Kurepa J, Toh-e A, Smalle J. 265 proteasome regulatory particle mutants have increased oxidative stress tolerance. Plant J. 2008;53:102-14.

27. Kurepa J, Smalle J, Van Montagu M, Inze D. Effects of sucrose supply on growth and paraquat tolerance of the late-flowering gi-3 mutant. Plant Growth Regul. 1998;26(2):91-6. 
28. Kurepa J, Smalle J, Van Montagu M, Inze D. Oxidative stress tolerance and longevity in Arabidopsis: the late-flowering mutant gigantea is tolerant to paraquat. Plant J. 1998;14(6):759-64.

29. Kurepa J, Smalle J, Van Montagu M, Inze D. Polyamines and paraquat toxicity in Arabidopsis thaliana. Plant Cell Physiol. 1998;39(9):987-92.

30. Kurepa J, Hérouart D, Van Montagu M, Inzé D. Differential expression of CuZn- and Fe-superoxide dismutase genes of tobacco during development, oxidative stress, and hormonal treatments. Plant Cell Physiol. 1997;38(4):463-70.
31. Kurepa J, Bueno P, Kampfenkel K, Vanmontagu M, Vanden Bulcke M, Inze $D$. Effects of iron deficiency on iron superoxide dismutase expression in Nicotiana tabacum. Plant Physiol Biochem. 1997;35(6):467-74.

32. Bueno P, Piqueras A, Kurepa J, Savoure A, Verbruggen N, Van Montagu $\mathrm{M}$, Inze D. Expression of antioxidant enzymes in response to abscisic acid and high osmoticum in tobacco BY-2 cell cultures. Plant Sci. 1998;138(1):27-34.

33. Müller-Xing R, Xing Q, Goodrich J. Footprints of the sun: memory of UV and light stress in plants. Front Plant Sci. 2014;5:474.
Ready to submit your research? Choose BMC and benefit from:

- fast, convenient online submission

- thorough peer review by experienced researchers in your field

- rapid publication on acceptance

- support for research data, including large and complex data types

- gold Open Access which fosters wider collaboration and increased citations

- maximum visibility for your research: over 100M website views per year

At BMC, research is always in progress.

Learn more biomedcentral.com/submissions 